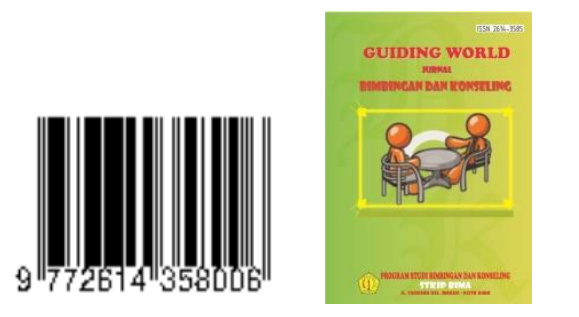

\title{
Upaya Meningkatkan Percaya Diri Peserta Didik Dengan Layanan Bimbingan Kelompok (Role Playing) Di SMPN 4 Kota Bima
}

\author{
Imriani, Muhamadiah, Sarbudin \\ Prodi Bimbingan dan Konseling, Sekolah Tinggi Keguruan Dan Ilmu Pendidikan (STKIP) Bima \\ Email:
}

\section{Abstrak}

Masalah penelitian ini adalah percaya diri siswa rendah. Permasalahannya adalah "apakah terdapat peningkatan rasa percaya diri siswa yang rendah dengan menggunakan layanan bimbingan kelompok (role playing) pada siswa kelas VII SMPN 4 Kota Bima." Tujuan penelitian untuk mengetahui peningkatan rasa percaya diri siswa yang rendah dengan menggunakan layanan bimbingan kelompok (role playing) di SMPN 4 Kota Bima. Kegunaan dalam penelitian ini adalah secara teoritis dan secara praktis. Asumsi yang di ajukan dalam penelitian ini adalah jika layanan bimbingan kelompok (role playing) efektif dan efesien diberikan maka dapat meningkatkan rasa percaya diri peserta didik di SMPN 4 Kota Bima. Penelitian ini menggunakan penelitian kunatitatif, penelitian ini bersifat preksperimen dengan jenis desain one group pretest-posttest, untuk mengetahui apakah ada peningkatan nilai antara pretest yang belum memberikan perlakuan dan posttest setelah memberikan perlakuan. Populasi dalam penelitian ini adalah seluruh siswa kelas VII SMPN 4 Kota Bima terdiri dari 4 kelas yang berjumlah 89 orang siswa. Sampel penelitian sebanyak 20 orang siswa kelas VII $^{2}$ yang memiliki percaya diri rendah. Instrumen dalam penelitian ini adalah angket yang berupa pretest dan postest. Teknik pengumpulan data menggunakan skala percaya diri dan bimbingan kelompok, untuk meningkatkan rasa percaya diri peserta didik di SMPN 4 Kota Bima. Hasil penelitian menunjukan bahwa terdapat peningkatan percaya diri dengan mengunakan layanan bimbingan kelompok dengan teknik role playing, dengan rata-rata peningkatan sebesar 10.50 terbukti dari hasi lanalisis data percaya diri menggunakan ujiwilcoxon, darihasi pretest dan posttest diperoleh $Z_{\text {hitung }}=-3,935>Z_{\text {tabel }} 0,05=1,645$.. Dengan demikian, Ho ditolak, artinya terdapat peningkatan percaya diri dengan menggunakan layanan bimbingan kelompok dengan teknik role playing pada siswa kelas VII di SMPN 4 Kota Bima.

Kata Kunci : Percaya Diri, Bimbingan Kelompok, Role Playing

\section{PENDAHULUAN}

Percaya diri merupakan suatu keyakinan dan sikap seseorang terhadap kemampuan yang ada pada dirinya sendiri dengan menerima secara apa adanay baik positif maupun 

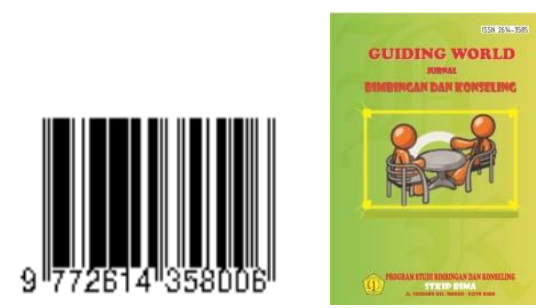

GUIDING WORLD JURNAL

BIMBINGAN DAN KONSELING

DOI: 1033627

Volume 03, Nomor 02

November 2020

E-ISSN: 2614-3585

negatif yang dibentuk dan dipelajarimelalui proses belajar dengan tujuan untuk kebahagiian dirinya. Rasa percaya diri merupakan suatu keyakinan terhadap segala aspek yang dimiliki dan keyakinan tersebut membuatnya merasa mampu untuk bisa mencapai berbagai tujuan dalam hidupnya" (Hakim, 2005: 6). Sedangkan menurut (Surya, 2007: 56) Rasa percaya diri merupakan sikap mental optimisme dari kesanggupan anak terhadap kemampuan diri untuk menyelesaikan segala sesuatu dan kemampuan diri untuk melakukan penyesuaian diri pada situasi yang dihadapi". Peserta didik yang memiliki rasa percaya diri yang rendah menurut Hakim (2002:72-83) biasanya menampakkan gejala merasa takut, menarik perhatian dengan cara kurang wajar, grogi saat tampil di depan kelas, timbul rasa malu yang berlebihan, sering mencontek dan mudah cemas. Percaya diri merupakan salah satu masalah yang banyak dikalangan remaja, peserta didik yang kurang percaya diri sangat sulit untuk mengembangkan diri, hal ini bisa dilihat saat mereka berada pada suatu kondisi dan situiasi tertentu.

Layanan bimbingan kelompok merupakan layanan bimbingan dan konseling yang memungkinkann siswa secara bersama-sama, melalui dinamika kelompok. Bimbingan kelompok dilaksanakan jika masalah yang dihadapi beberapa peserta didik relatif mempunyai kesamaan atau saling mempunyai hubungan serta mereka mempunyai kesediaan untuk dilayani secara kelompok.

Berdasarkan hasil opservasi dan wawancara yang dilakukan dengan guru bimbingan dan konseling di SMPN 4 Kota Bima, bahwa banyak siswa kurang percaya diri sering kali berprilaku yang tidak sepantasnya dilakukan oleh peserta didik. Perilaku mencontek dengan temannya saat mengerjakan tugas baik saat ujian atau tugas-tugas harian, sering mengeluh terhadap diri sendiri, merasa pesimis tidak mampu apabila disuruh untuk mengerjakan tugas tertentu, merokok karena takut dikucilkan oleh teman-temannya, mudah putus asa, malu-malu dan sering menyendiri dari teman-temannya.

Berdasarkan uraian diatas peneliti tertarik untuk menerapkan layanan bimbingan kelompok (role playing) yang membimbing peserta didik untuk meningkatkan rasa percaya diri dan mampu menerima dirinya, berfikir posistif, berwibawa, serta bertanggung jawab pada diri sendiri maupun orang lain. Usaha ini di implementasikan dalam penelitian yang berjudul "upaya meningkatkan rasa percaya diri siswa melalui bimbingan kelompok (role playing) peserta didik kelas VII SMPN 4 Kota Bima.

Rumusan masalah dalam penelitian ini adalah apakah penerapan layanan bimbingan kelompok (role playing) dapat meningkatkan rasa percaya diri peserta didk kelas VII di SMPN 4 Kota Bima.

\section{KERANGKA TEORITIS DAN PENGEMBANGAN HIPOTESIS}

\section{Percaya Diri}

\section{Pengertian Percaya Diri}

Percaya diri merupakan modal dasar untuk pengembangan dalam aktualisasi diri (eksplorasi segala kemampuan dalam diri). Dengan percaya diri seseorang akan mampu mengenal dan memahami diri sendiri. Menurut Maslow dalam (Iswidharmanjaya \& Agung, 2004 : 13). Hal yang sama juga disampaikan oleh (Angelis, 2007: 10). Percaya diri merupakan suatu keyakinan dalam jiwa manusia bahwa tantangan hidup apapun harus dihadapi dengan berbuat 


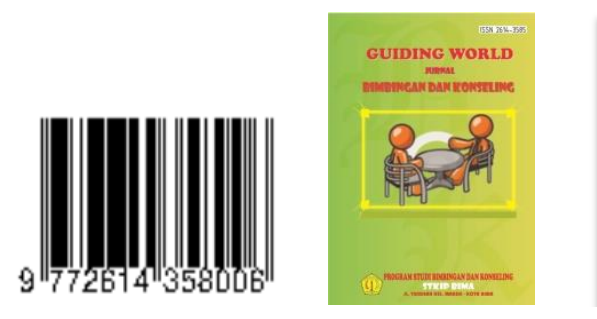

sesuatu. Percaya diri itu lahir dari kesadaran bahwa jika memutuskan untuk melakukan sesuatu, sesuatu itu pula yang harus dilakukan. Pendapat tersebut didukung juga olehHasan dkk. dalam (Iswidharmanjaya \& Agung, 2004 : 13) Percaya diri adalah kepercayaan akan kemampuan sendiri yang memadai dan menyadari kemampuan yang dimiliki, serta dapat memanfaatkannya secara tepat. Berdasarkan beberapa pengertian diatas maka dapat ditarik kesimpulan bahwa percaya diri adalah kesadaran individu akan kelebihan dan kelemahan yang dimilikinya dan kesadaran tersebut membuatnya merasa yakin pada kemamapuan yang dimiliki, menerima diri, bersikap optimis, dan berfikir positif. Sehingga dapat bertindak sesuai dengan kapasitasnya serta mampu mengendalikanya.

\section{Faktor-Faktor Yang Mempengaruhi Pembentukan Rasa Percaya Diri}

Menurut Hakim (2002:121) adapun faktor-faktor yang mempengaruhi percaya diri yang paling mendasar adalah :

a. Pola asuh dan interaksi di usia dini

Sikap orang tua akan diterima anak sesuai dengan persepsinya pada saat itu. Orang tua yang menunjukkan kasih sayang, cinta dan penerimaan serta kelekatan emosional akan membangkitkan rasa percaya diri pada anak tersebut. Anak akan merasa dihargai dan dikasihi. Meskipun anak melakukan kesalahan, dari sikap orang tua anak melihat bahwa dirinya dihargai bukan tergantung pada prestasi ataupun perbuatan baiknya, namun karena eksistensinya. Anak akan tumbuh menjadi individu yang mampu menilai positif dirinya dan memiliki harapan yang realistik. Orang tua dan masyarakat seringkali meletakkan standar harapan yang kurang realistik terhadap anak. Sikap suka membanding-bandingkan anak, mempergunjingkan kelemahan anak, tanpa sadar menjatuhkan harga diri anak tersebut. Situasi ini pada akhirnya mendorong anak menjadi individu yang tidak bisa menerima kenyataan dirinya, karena merasa malu. Rasa percaya diri begitu lemah dan ketakutannya semakin besar.

b. Pola pikir yang negatif

Reaksi individu terhadap seseorang ataupun sebuah peristiwa dipengaruhi oleh cara berpikirnya. Individu dengan rasa percaya diri yang rendah cenderung mempersepsi segala sesuatu dari sisi negatif. Ia tidak menyadari bahwa dari dalam dirinyalah semua negativisme itu berasal. Rasa tidak percaya diri berawal dari kelemahan individu pada berbagai aspek kepribadiannya terutama yang berasal dari keluarga. Pemahaman negatif yang akan muncul pada diri seseorang maupun lingkungan sehingga ia meyakini bahwa dirinya tidak memiliki kelebihan. Akibatnya perilaku dalam kehidupan pribadi dan sosialnya kurang baik.

\section{Bimbingan Kelompok}

\section{Pengertian Bimbingan Kelompok}

Bimbingan kelompok merupakan salah satu pengalaman melalui pembentukan kelompok yang khas untuk keperluan pelayanan bimbingan. Menurut Winkel dan Sri Hastuti (2006: 564). Menurut pendapat Romlah (2003: 3) bimbingan kelompok adalah salah satu teknik bimbingan yang berusaha membantu individu agar dapt mencapai perkembangannya secara otimal sesuai dengan kemampuan, bakat, minat, serta nilai-nilai yang di anutnya dan dilaksanakan dalam situasi kelompok. Menurut (Sukardi, 2003:48) Layanan bimbingan 

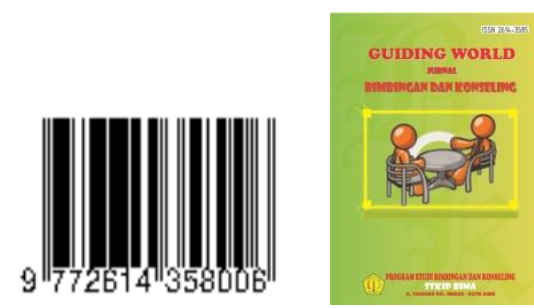

DOI: 1033627

Volume 03, Nomor 02

November 2020

E-ISSN: 2614-3585

kelompok dimaksudkan untuk memungkinkan peserta didik secara bersama-sama memperoleh berbagai bahan dari nara sumber (terutama guru pembimbing) yang bermanfaat untuk kehidupan sehari-hari baik sebagai individu maupun sebagai pelajar, anggota keluarga dan masyarakat. Dilanjutkan oleh Wibowo (2005: 17) menyatakan bahwa bimbingan kelompok adalah suatu kegiatan kelompok dimana pimpinan kelompok menyediakan informasi-informasi dan mengarahkan diskusi agar anggota kelompok menjadi lebih sosial atau untuk membantu anggota-anggota kelompok untuk mencapai tujuan-tujuan bersama.

Berdasarkan beberapa pengertian di atas dapat disimpulkan bahwa bimbingan kelompok merupakan salah satu bentuk bimbingan yang dilakukan melalui media kelompok dengan memanfaatkan dinamika kelompok yang bertujuan untuk menggali dan mengembangkan diri dan potensi yang dimiliki individu.

\section{Tujuan Bimbingan Kelompok}

Kesuksesan layanan bimbingan kelompok sangat dipengaruhi oleh sejauh mana keberhasilan tujuan yang akan dicapai dalam layanan bimbingan kelompok yang diselenggarakan. Tujuan bimbingan kelompok Menurut Romlah (2003: 14-15) memberikan kesempatan-kesempatan pada peserta didik belajar hal-hal penting yang berguna bagi pengarahan dirinya yang berkaitan dengan masalah pendidikan, pekerjaan, pribadi dan sosial, memberikan layanan-layanan penyembuhan melalui kegiatan kelompok, untuk mencapai tujuan-tujuan bimbingan secara lebih ekonomis dan efektif dari pada melalui kegiatan bimbingan individual, serta untuk melaksanakan layanan konseling individual secara lebih efektif.

\section{Tahap-Tahap Pelaksanaan Bimbingan Kelompok}

Pada umumnya, terdapat empat tahap dalaam bimbingan kelompok yaitu tahap pembentukan, peralihan, pelaksanaan kegiatan dan pengakhiran.

Uraian berikut akan mengemukakan gambaran dari keempat tahap secara ringkas

a. Tahap I (Pembentukan)

Tahap ini merupakan tahap pengenalan, tahap perlibatan diri atau tahap memasukkan diri ke dalam kehidupan suatu kelompok. Pada tahap ini para anggota saling memperkenalkan diri dan juga mengungkapkan tujuan atau harapan-harapan yang ingin dicaapai baik oleh masing-masing, sebagian, maupun seluruh anggota. Tahap ini merupakan masa keheningan dan kecanggungan. Para anggota mulai mempelajari perilaku-perilaku dasar dari menghargai, empati, penerimaan, perhatian dan menanggapi semua perilaku yang membangun kepercayaan. Dalam tahap ini anggota kelompok mulai belajar untuk terlibat dalam interaksi kelompok.

b. Tahap II (Peralihan)

Tahap kedua, tahap peralihan atau transisi. Pada tahap ini suasana kelompok mulai terbentuk dan dinamika kelompok sudah mulai tumbuh. Karakteristik tahap transisi ditandai perasaan ditandai perasaan khawatir, defence (bertahan) dan berbagai bentuk perlawanan. Pada kondisi demikian pemimpin kelompok perlu untuk memberikan motivasi dan reinforcement kepada anggota agar mereka 


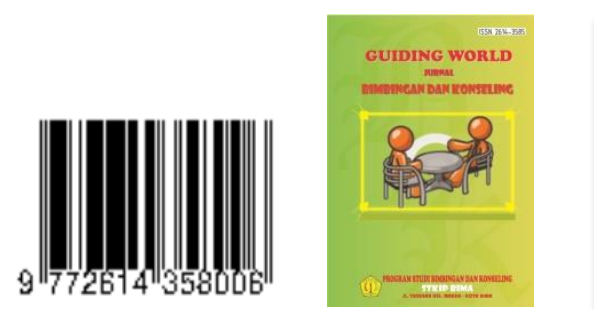

peduli tentang apa yang dipikirkannya dan belajar mengekspresikan diri sehingga anggota lain bisa mendengarkan.

c. Tahap III (Kegiatan)

Tahap ini merupakan inti kegiatan kelompok sehingga aspek-aspek yang menjadi isi pengiringnya cukup banyak. Pada kegiatan ini saatnya anggota berpartisipi untuk menyadari bahwa merekalah yang bertanggung jawab atas kehidupan mereka. Jadi mereka harus didorong untuk mengambil keputusan, pendapat dan tanggapan mengenai topik atau masalah yang di hadapi untuk di gali dalam kelompok, dan belajar bagaimana menjadi bagian kelompok yang integral sekaligus memahami kepribadiannya sendiri dan juga dapat memahami orang lain serta dapat menyaring umpan balik yang diterima dan membuat bkesimpulan yang komprehensif dari berbagai pendapat masukan-masukan dalam pembahasan kelompok dan memutuskan apa yang harus dilakukannya nanti.

Kegitan-kegiatan yang harus dilakukan pada tahap ini, adalah: masing-masing anggota secara bebas menemukakan pendapat terhadap topik atau masalah, menetapkan topik atau masalah yang akan dibahas terlebih dahulu, anggota membahas masing-masing topik atau masalah secara mendalam dan tuntas, kegiatan selingan. Adapun fungsi utama dari pemimpin pada tahap kegiatan ini adalah memberikan penguatan secara sistematis dari tingakah laku kelompok yang di inginkan. Selain itu dapat memberikan dukungan pada kesukarelaan anggota untuk mengambil resiko dan mengarahkan untuk menerapkan untuk menerapkan tingkah laku dalam kehidupan sehari-hari.

d. Tahap IV (Pengakhiran)

Tahap keempat adalah tahap akhir yang merupakan konsolidasi dan terminasi. Pada tahap ini "pokok perhatian utama bukanlah pada beberapa kali kelompok itu harus bertemu namun pada hasil yang telah dicapai oleh kelompok ketika menghentikan pertemuan.

Selama tahap akhir kelompok akan muncul sedikit kecemasan dan kesedihan terhadap kenyataan perpisahan. Para anggota memutuskan tindakan-tindakan apa yang harus mereka ambil. Tugas utama yang di hadapi para anggota selama tahap akhir yaitu mentransfer apa yang telah mereka pelajari dalam kelompok ke dunia luar. Kegiatan-kegiatan yang harus dilakukan pada tahap ini, adalah: pemimpin kelompok menyatakan bahwa kegiatan akan segera diakhiri, pemimpin dan anggota kelompok mengemukakan kesan dan hasil-hasil kegiatan, membahas kegiatan lanjutan, mengemukakan pesan dan harapan.

Peranan pemimpin kelompok adalah tetap mengusahakan suasana yang hangat, memberikan pernyataan dan mengucapkan terima kasih atas keikutsertaan anggoat serta memberi semangat untuk kegiatan lebih lanjut dengan penuh rasa persahabatan dan simpati, di samping itu fungsi pemimpin kelompok pada tahap ini adalah memperjelas arti dari tiap pengalaman yang diperoleh melalui kelompok dan mengajak para anggota untuk menerapkan dalam kehidupan seharihari serta menekankan kembalin akan pentingnya pemeliharaan hubungan antar anggota setelah kelompok berakhir. 


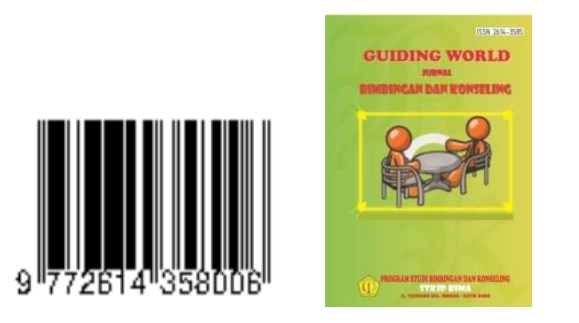

Setelah semua tahap di atas telah terlaksana, kemudian diadakan evaluasi dan follow up. Follow up dapat dilaksanakan secara kelompok maupun secara individu. Pada kegiatan tindak lanjut ini para anggota kelompok dapat membicarakan tentang upaya-upaya yang telah ditempuh. Mereka dapat melaporkan tentang kesulitan-kesulitan yang mereka temui, berbagai kesukacitaan dan keberhasilan dalam kelompok. Para anggota kelompok menyampaikan tentang pengalaman mereka dan hasilnya selama mengikuti kegiatan bimbingan kelompok dalam kehidupan sehari-hari.

Pemimpin kelompok dapat mengadakan evaluasi dengan memberikan pertanyaan atau wawancara dengan batas tertentu dan dilihat apakah anggota sudah dapat menguasai topik yang dibicarakan atau belum. Hal tersebut dapat memberi gambaran akan keberhasilan kegiatan kelompok.

\section{Role Playing}

\section{Pengertian Role Playing}

Menurut Wahab, A. A (2009: 109) Dilanjudkan oleh Blatner (2002), role playing adalah sebuah metode untuk mengeksplorasi hal-hal yang menyangkut situasi social yang kompleks.Ahmadi (2011: 54) Bermain Peran (role playing) "adalah suatu cara penguasaan bahan-bahan pelajaran melalui pengembangan imajinasi dan penghayatan siswa". Pengembangan imajinasi dan penghayatan dilakukan siswa dengan memerankannya sebagai tokoh hidup atau benda mati. Permainan ini umumnya dilakukan lebih dari satu orang, hal ini bergantung kepada apa yang diperankan.

Pembelajaran dengan role playing adalah suatu cara penguasaan bahan-bahan pelajaran melalui pengembangan imajinasi dan penghayatan siswa. Pengembangan imajinasi dan penghayatan itu dilakukan siswa dengan memerankannya sebagai tokoh hidup atau benda mati. Metode ini banyak melibatkan siswa dan membuat siswa senang belajar serta metode ini mempunyai nilai tambah, yaitu: a) dapat menjamin poartisipasi seluruh siswa dan memberi kesempatan yang sama untuk menunjukkan kemampuannya dalam bekerjasama hingga berhasil, dan b) permainan merupakan pengalaman yang menyenangkan bagi siswa Prasetyo, (2001:72).

Dari berbagai persepsi diatas dapat disimpulkan, metode role playing (bermain peran) adalah sebuah metode untuk mengembangkan kreatifitas siswa dengan menggunakan dinamika kelompok dan berusaha untuk memerankan sebuah peranan yang sesuai dengan kemampuan siswa.

\section{Tujuan dan Manfaat Metode Role Playing}

Model pembelajaran role play lebih menekankan hubungan individu dengan masyarakat atau orang lain. Model ini lebih memfokuskan pada proses negosiasi sosial. Dalam upaya peningkatan kemampuan individu untuk berhubungan dengan orang lain dalam upaya meningkatkan proses demokratis, didesain untuk mengajak peserta didik dalam menyelidiki nilai-nilai pribadi dan sosial melalui tingkah laku mereka sendiri dan nilai-nilai yang menjadi sumber penyelidikan. 


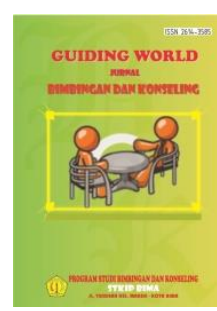

DOI: 1033627

Manfaat yang dapat diambil dari role playing adalah: Pertama, role playing dapat memberikan semacam hidden practise, dimana murid tanpa sadar menggunakan ungkapanungkapan terhadap materi yang telah dan sedang mereka pelajari. Kedua, role playing melibatkan jumlah murid yang cukup banyak, cocok untuk kelas besar. Ketiga, role playing dapat memberikan kepada murid kesenangan karena role playing pada dasarnya adalah permainan. Dengan bermain murid akan merasa senang karena bermain adalah dunia siswa. Masuklah ke dunia siswa, sambil kita antarkan dunia kita (Bobby DePorter, 2000: 12).

\section{Langkah-Langkah Pembelajaran Metode Role Playing}

Shaftel dan Shaftel, E. Mulyasa (2011) mengemukakan tahapan pembelajaran bermain peran meliputi:

(1). Menghangatkan suasana dan memotivasi peserta didik.

Menghangatkan suasana kelompok termasuk mengantarkan peserta didik terhadap masalah pembelajaran yang perlu dipelajari. Hal ini dapat dilakukan dengan mengidentifikasi masalah, menjelaskan masalah, menafsirkan cerita dan mengeksplorasi isu-isu, serta menjelaskan peran yang akan dimainkan. Tahap ini lebih banyak dimaksudkan untuk memotivasi peserta didik agar tertarik pada masalah karena itu tahap ini sangat penting dalam bermain peran dan paling menentukan keberhasilan. Bermain peran akan berhasil apabila peserta didik menaruh minat dan memperhatikan masalah yang diajukan guru.

(2). Memilih peran

Memilih peran dalam pembelajaran, tahap ini peserta didik dan guru mendeskripsikan berbagai watak atau karakter, apa yang mereka suka, bagaimana mereka merasakan, dan apa yang harus mereka kerjakan, kemudian para peserta didik diberi kesempatan secara sukarela untuk menjadi pemeran.

(3). Menyusun tahap-tahap peran

Menyusun tahap-tahap baru, pada tahap ini para pemeran menyusun garis-garis besar adegan yang akan dimainkan. Dalam hal ini, tidak perlu ada dialog khusus karena para peserta didik dituntut untuk bertindak dan berbicara secara spontan.

\section{(4). Menyiapkan pengamat}

Menyiapkan pengamat, sebaiknya pengamat dipersiapkan secara matang dan terlibat dalam cerita yang akan dimainkan agar semua peserta didik turut mengalami dan menghayati peran yang dimainkan dan aktif mendiskusikannya.

\section{(5). Pemeranan}

Pada tahap ini para peserta didik mulai beraksi secara spontan, sesuai dengan peran masing-masing. Pemeranan dapat berhenti apabila para peserta didik telah merasa cukup, dan apa yang seharusnya mereka perankan telah dicoba lakukan. Ada kalanya para peserta didik keasyikan bermain peran sehingga tanpa disadari telah mamakan waktu yang terlampau lama. Dalam hal ini guru perlu menilai kapan bermain peran dihentikan.

(6). Diskusi dan evaluasi

Diskusi akan mudah dimulai jika pemeran dan pengamat telah terlibat dalam bermain peran, baik secara emosional maupun secara intelektual. Dengan melontarkan sebuah pertanyaan, para peserta didik akan segera terpancing untuk diskusi.

(7). Pemeranan ulang 


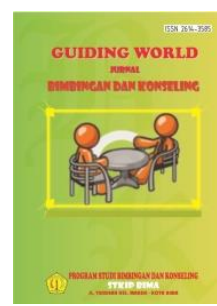

Pemeranan ulang, dilakukan berdasarkan hasil evaluasi dan diskusi mengenai alternatif pemeranan. Mungkin ada perubahan peran watak yang dituntut. Perubahan ini memungkinkan adanya perkembangan baru dalam upaya pemecahan masalah. Setiap perubahan peran akan mempengaruhi peran lainnya.

(8). Diskusi dan evaluasi tahap dua

Diskusi dan evaluasi tahap dua, diskusi dan evaluasi pada tahap ini sama seperti pada tahap enam, hanya dimaksudkan untuk menganalisis hasil pemeranan ulang, dan pemecahan masalah pada tahap ini mungkin sudah lebih jelas.

(9). Membagi pengalaman dan mengambil kesimpulan

Pada tahap ini para peserta didik saling mengemukakan pengalaman hidupnya dalam berhadapan dengan orang tua, guru, teman dan sebagainya. Semua pengalaman peserta didik dapat diungkap atau muncul secara spontan

\section{METODE}

Jenis penelitian ini adalah pre experiment (eksperiment tidak sebenarnya) atau quasi experiment. Peneliti menggunakan one group pre-test and post-test design karena tidak ada perbandingan dengan kelompok kontrol, sehingga satu kelompok tes diberikan satu perlakuan yang sama sebelum dan sesudah mendapatkan perlakuan tertentu. Dalam penelitian ini yang menjadi populasi penelitian adalah siswa kelas VII ${ }^{2}$ sebanyak 89 peserta didik. Jumlah sampel yang diambil pada penelitian ini adalah 20 orang diambil dari kelas VII ${ }^{2}$. Adapun tehnik pengumpulan data menggunakan observasi, angkat dan dokumentasi. Instrumen dalam penelitian ini adalah angket yang berupa pretest dan postest. Teknik pengumpulan data menggunakan skala percaya diri dan bimbingan kelompok, untuk meningkatkan rasa percaya diri peserta didik di SMPN 4 Kota Bima. Tehnik analisa data menggunakan dengan uji Wilcoxon yaitu dengan mencari perbedaan mean Pretest dan Posttest.

\section{HASIL DAN PEMBAHASAN (12pt bold Styles Heading 1)}

1. Data Hasil Penelitian Pretest dan postest

Hasil dari pretest dan postest yang dilakukanpada sampel yang telah ditentukan yaitu kelas $\mathrm{VII}^{2}$, pretest yang diberikan sebelum memberikan treatmen dan postest diberiakan setelah diberikan treatmen, pada kelas yang sama untuk mengetahui pengaruh metode bimbingan kelompok dengan teknik role playing (bermain peran) dalam upaya meningkatkan percaya diri siswa di SMPN 4 Kota Bima.

Tabel 4.1: Data Skor hasil Pretest dan Postest, tentang upaya meningkatkan percaya diri siswa melalui bimbingan kelompok dengan teknik role playing (bermain peran)

\begin{tabular}{|c|c|c|}
\hline NO & PRE TEST & POSTEST \\
\hline 1 & 55 & 59 \\
\hline 2 & 50 & 55 \\
\hline 3 & 55 & 58 \\
\hline
\end{tabular}

67 

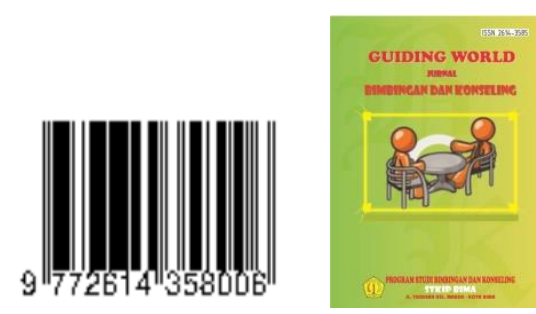

GUIDING WORLD JURNAL

BIMBINGAN DAN KONSELING

Volume 03, Nomor 02

November 2020

E-ISSN: 2614-3585

DOI: 1033627

\begin{tabular}{|c|c|c|}
\hline 4 & 44 & 50 \\
\hline 5 & 42 & 50 \\
\hline 6 & 45 & 51 \\
\hline 7 & 57 & 59 \\
\hline 8 & 50 & 55 \\
\hline 9 & 62 & 64 \\
\hline 10 & 51 & 57 \\
\hline 11 & 51 & 56 \\
\hline 12 & 57 & 60 \\
\hline 13 & 49 & 58 \\
\hline 14 & 47 & 50 \\
\hline 15 & 59 & 61 \\
\hline 16 & 38 & 49 \\
\hline 17 & 59 & 62 \\
\hline 18 & 54 & 59 \\
\hline 19 & 59 & 61 \\
\hline 20 & 57 & 60 \\
\hline JUMLAH & 1040 & 1134 \\
\hline
\end{tabular}

Tabel 4.2:Untuk mengkur nilai rata-rata untuk membuktikan besar seperbedaan antara nilai pretest dan postest, dengan menggunakan uji wilcoxon

Descriptive Statistics

\begin{tabular}{|l|l|l|l|l|l|}
\hline & & & $\begin{array}{l}\text { Std. } \\
\text { Deviation }\end{array}$ & Minimum & Maximum \\
\hline Pretest & 20 & 52.05 & 6.476 & 38 & 62
\end{tabular}

68 


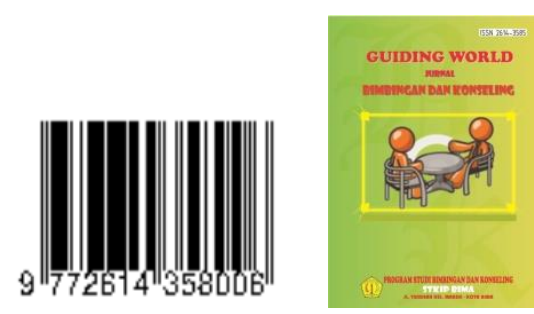

DOI: 1033627

Descriptive Statistics

\begin{tabular}{|l|l|l|l|l|l|}
\hline & & Mean & $\begin{array}{l}\text { Std. } \\
\text { Deviation }\end{array}$ & Minimum & Maximum \\
\hline Pretest & 20 & 52.05 & 6.476 & 38 & 62 \\
Postest & 20 & 56.70 & 4.543 & 49 & 64 \\
\hline
\end{tabular}

Dari tabel dapat kita lihat bahwa ada perbedaan nilai antara hasil pretest dan pn ostest yang diberkan kepada siswa, untuk mengukur hasil peningkatan percaya diri siswa dengan menggunkan metode bimbingan kelompok dengan teknik role playing

Dari masing-masing kelompok data (pretest dan posttest), tampak bahwa mean atau rata-rata nilai postest 56,70 dimana lebih besar dari pada nilai pretest yaitu 52,05 berarti metode bimbingan kelompok dengan teknik role playing dapat meningkatkanpercaya diri siswa kelas VII SMPN 4 Kota Bima.

Tabel 4.3: untuk mengukur nilai selisi antara rank negatif dan rank positif, menggunakan hitungan SPSS

\section{Ranks}

\begin{tabular}{|c|l|l|l|}
\hline & $\mathrm{N}$ & Mean Rank & Sum of Ranks \\
\hline postest - pretest Negative Ranks & $0^{\mathrm{a}}$ & .00 & .00 \\
Positive Ranks & $20^{\mathrm{b}}$ & 10.50 & 210.00 \\
Ties & $0^{\mathrm{c}}$ & & \\
Total & 20 & & \\
\hline
\end{tabular}

a. postest < pretest

b. postest $>$ pretest

c. postest $=$ pretest

Dari hasil data diatas bahwa, Negative Ranks atau selisi (negative) antara hasil pretest dan posttest adalah 0, baik itu pada nilai N, Mean Ranks maupun Sum Rank nilai 0 ini menunjukkan tidak ada penurunan (penggurangn) dari nilai pretes ke nilai posttest.

Positif Rank atau selisi positif antara hasil postest dan pretest disini terdapat 20dan datapositif $\mathrm{N}$ yang artinya ke 20siswa mengalami peningkatan hasil dari nilai pretest ke nilai postest. Mean Rank atau rata-rata peningkatan tersebut adalah sebesar 10,50, sedangkan jumlah rangking positif atau Sum of Rank adalah sebesar 210,00

Ties adalah kesamaan nilai pretes dan postest disini nilai Ties adalah 0 , sehingga data dikatakan bahwa tidak ada nilai yang sama antara pretest dan postest.

\section{Pengujian hipotesis}

Hasil yang diperoleh dalam penelitian ini menunjukkan bahwa percaya diri pada siswa mengalami peningkatan setelah pemberian layanan konseling kelompok. Hal ini terbukti darihasil uji hipotesis dengan peningkatan rata-rata sebesar 10,50 yang terlihat di tabel 4.3 

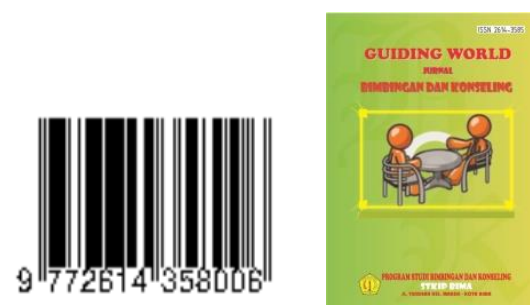

GUIDING WORLD JURNAL

BIMBINGAN DAN KONSELING

DOI: 1033627

Volume 03, Nomor 02

November 2020

E-ISSN: 2614-3585

Tabel 4.4: Data Test Statistic, untuk menggukur apakah ada perubahan antara nilai pretest dan posttest.

Test Statistics ${ }^{\mathrm{b}}$

\begin{tabular}{|l|l|}
\hline & postest - pretest \\
\hline $\mathrm{Z}$ & $-3.935^{\mathrm{a}}$ \\
Asymp. Sig. (2-tailed) & .000 \\
\hline
\end{tabular}

a. Based on negative ranks.

b. Wilcoxon Signed Ranks Test

Berdasarkan tabel diatas dapat dilihat bahwa nilai sig (2-tailed) 0,00 sehingga dengan demikian nilai signifikansi 5\% atau 0.05 dapat dilihat bahwa Asymp sig ( 2 -tailad) $0,00<0,05$ Hoditolak, artinya terdapat peningkatan percaya diri dengan menggunakanlayanan bimbingan kelompok dengan teknik (role playing) pada siswa kelas VII ${ }^{2}$ SMP 4 Kota Bima.

Setelah melakukan penelitian pada kelas yang menjadi sampel pemberian perlakuan dengan menggunakan metode bimbingan kelompok (role playing), dari hasil tes terakhir siswa setelah melakukan metode bimbingan kelompok, seperti yang terliat dari tabelhasil pretest dan hasil postest diperoleh hasil hipotesis dengan taraf siknifikan 5\%dimana $\mathrm{Z}_{\text {-hitung }}=$ 3.935 lebih besar dari $Z_{\text {-tabel }}=1.697$ hal ini menujukan kedua sampel mempunyai perbedaan tingkat kemampuan hasil bimbingan antara sebelum pemberian perlakuan maka Ho ditolak dan Ha diterima sehingga dapat ditarik kesimpulan bahwa perlakuan yang diberikan dengan menggunakan metode bimbingankelompok berpengaruh terhadap hasil tingkat percaya diri peserta didik. Hal ini sejalan dengan hasil penelitian Devitasari (2015), dimana ada perubahan-perubahan perilaku kesembilan subyek penelitian yang sebelum diberikan perlakuan memiliki percaya diri yang rendah, tetapi setelah diberi perlakukan dengan layanan konseling kelompok (role playing) percaya diri kesembilan subyek meningkat.

Berdasarkan uraian diatas bahawa ada peningkatan percaya diri peserta didik dengan menggunakan layanan bimbingan kelompok dengan teknik role playing, diuiji dengan pretest dan postest, pretest, diberikan sebelum melakuakn perlakuan dan postest diberikan setelah memberikan perlakuan.

\section{PENUTUP (12pt bold Styles Heading 1)}

Berdasarkan hasil analisis data dan pembahasan dalam penelittian yang dilaksanakan di SMPN Kota Bima tahun pelajaran 2017/2018, pada kelas yang telah ditentukan, dengan menggunakan data hasil nilai dari pretest dan postest, didapatkan bahwa nilai $Z=_{\text {hitung }}>T_{\text {tabel }}$ sebesar 3,935 > 1,695 pada taraf siknifikan 5\% hal ini menunjukan adanya perbedaan nilai rata-rata antara nilai rata-rata pretest dan nilai postest, dimana nilai rata-rata postest 56,07 lebih besar dari nilai pretest yaitu 52,05, maka dapat disimpulkan bahwa "metode bimbingan kelompok dengan teknik role playing dapat berpengaruh terhadap tingkat percaya diri siswa kelas VII ${ }^{2}$ SMPN Kota Bima. 


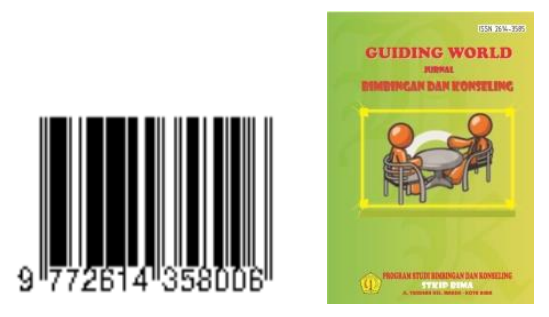

DOI: 1033627

Volume 03, Nomor 02

November 2020

E-ISSN: 2614-3585

\section{DAFTAR PUSTAKA (12pt bold Styles Heading 1)}

[1] Arikunto, Suharsimi, 2013. Suatu Pendekatan Praktek, cetak kelima belas, Jakarta: Rineka cipta.

[2] Desmita, 2009, Psikologi Perkembangan Peserta Didik. Bandung: Remaja Rosdakarya.

[3] Devitasari, 2015. Peningkatan Percaya Diri Peserta Didik Menggunakan Layanan Konseling Kelompok (role playing). Universitas Lampung Bandar lampung

[4] Hartina, Sitti. (2009), Konsep Dasar Bimbinga Kelompok. Bandung: refika Aditama.

[5] Rusman, Nandang. (2009), Bimbingan dan Konseling Kelompok di Sekolah (metode, tehnik dan aplikasi). Bandung : Rizqi press, cetakan pertama

[6]Sholihin, Ibnu Ubaydillah. (2013), Kajian Teori: Hakikat Metod Pembelajaran RolePlaying. (online) diakses dari http:// rujukan skripsi.blogspot.com/2013/06/kajian-teori-hakikat-metode.html.

[7] Sandjaja. Heriyanto, Albertus. 2006. Panduan Peneitian. Jakarta: Prestasi Pustaka

[8] Sagala, Syaiful. 2010. Konsep dan Makna Pembelajaran:Untuk Membantu Memecahkan Problematika Belajar dan Mengajar.Bandung . (online) diakses dari : http://bit.ly/gadgets_cheap

[9] Tirtarahardja, Umar. dan La, Sulo S.L. 2005. Pengantar Pendidikan. Jakarta: PT Rinekacipta (online) diakses dari http:// pendantropologi09.blogspot.co.id/2011/11/konsep-pendidikan-berdasarkan-uud1945.html

[10] Pranoto, Hadi, 2016. Upaya Meningkatkan Percaya Diri Peserta Didik Melalui Layanan Bimbingan Kelompok. Universitas Muhamadiyah Metro.

[11] Willis, Sofyan S. 2005. Remaja dan masalahnya. Bandung : Alfabeta.

[12] Wibowo, Mungin Edi. 2005. "Konseling Kelompok Perkembangan". Semarang: UNNES Press.(online), Diakses dari https://ewintri.wordpress.com/2012/01/02/bimbingan-kelompok/

[13] Yusuf Syamsu, Nurihsan Juntika, 2012. Landasan Bimbingan dan Konseling. Bandung: PT Remaja rosdakarya. 